The Agriculturists 16(2): 25-34 (2018) ISSN 2304-7321 (Online), ISSN 1729-5211 (Print)

A Scientific Journal of Krishi Foundation

Indexed Journal

DOI: http://dx.doi.org/ 10.3329/agric.v16i02.40340

Impact Factor: 0.568 (GIF, 2015)

\title{
Effect of Mulches and Phosphorus on Growth and Yield of Squash (Cucurbita pepo)
}

\author{
F. Akhter*, T. Mostarin, M. N. Islam, S. Akhter and A. Parvin \\ Sher-e- Bangla Agricultural University, Sher-e- Bangla Nagar, Dhaka-1207 \\ *Corresponding author and Email: akhterfaiza21@gmail.com
}

Received: 30 September 2018

Accepted: 25 December 2018

\begin{abstract}
This study was conducted at the Horticultural Farm of Sher-e-Bangla Agricultural University, Dhaka during October, 2015 to January, 2016 to determine the effects of mulches and phosphorus on the growth and yield of squash (Cucurbita pepo). The experiment consisted of two factors. Factor A: different mulches and Factor B: phosphorus (3 levels). The experiment was laid out in a Randomized Complete Block Design with three replications. Mulches and phosphorus showed significant effects on most of the parameters. In case of mulches, highest individual fruit weight $(328.0 \mathrm{~g})$ and fruit yield $\left(37.0\right.$ tha $\left.^{-1}\right)$ was recorded from black polythene, whereas the lowest fruit weight $(280.8 \mathrm{~g})$ and fruit yield $\left(21.5\right.$ tha $\left.^{-1}\right)$ was recorded from control. In case of phosphorus, highest individual fruit weight $(300.4 \mathrm{~g})$ and fruit yield $\left(31.3 \mathrm{tha}^{-1}\right)$ was recorded from $90 \mathrm{~kg} \mathrm{P}_{2} \mathrm{O}_{5} /$ ha whereas the lowest fruit weight $(290.4 \mathrm{~g})$ and fruit yield $\left(26.2 \mathrm{tha}^{-1}\right)$ was recorded from control. For combination, highest individual fruit weight $(338.2 \mathrm{~g})$ and fruit yield $\left(39.9 \mathrm{t} \mathrm{ha}^{-1}\right)$ were recorded from black polythene with $90 \mathrm{~kg}$ $\mathrm{P}_{2} \mathrm{O}_{5} /$ ha while the lowest individual fruit weight $(272.2 \mathrm{~g})$ and fruit yield $\left(19.7 \mathrm{tha}^{-1}\right)$ were recorded from control treatment. Black polythene mulch with $90 \mathrm{~kg} \mathrm{P}_{2} \mathrm{O}_{5} /$ ha was found suitable for squash cultivation under the condition of the study.
\end{abstract}

Keywords: Squash, mulches, phosphorus.

\section{Introduction}

Squash (Cucurbita pepo L.) belongs to the family Cucurbitaceae and is grown throughout the world in both temperate and tropical climatic zones. In Bangladesh, this crop is relatively new but is increasingly gaining high levels of economical importance both in generation of income and provision of nutritional value. Squash has various health benefits to human as well as medicinal potentials (Mohammad et al., 2011). It is rich in nutrients and bioactive compounds contents such as phenolics, flavonoids, vitamins (including $\beta$-carotene, vitamin $\mathrm{A}$, vitamin $\mathrm{B} 2, \alpha$-tocopherol, vitamin $\mathrm{C}$, and vitamin E), amino acids, carbohydrates and minerals (especially potassium), and it is low in energy content (about $17 \mathrm{Kcal} / 100 \mathrm{~g}$ of fresh squash) and has large amount of fiber (Tamer et al., 2010). Squash is cultivated in Bangladesh during the winter season when rainfall is scanty and its growth and development is required optimum temperature within $18-25{ }^{\circ} \mathrm{C}$ (Albert, 2018). Most of the time irrigation and weed management increases the total cost of production of crops and ultimately growers can be frustrated. Mulching can reduce the water loss from the soil by evaporation which can minimize the requirement of water, suppression of weed and is thus, helpful in conserving soil moisture 
for the succeeding season to produce squash successfully particularly where rainfall and irrigation facilities are limited.

Application of different mulches such as black polythene, water straw, water hyacinth, saw dust, leaves, hay, shredded bark, shells, woodchips, newspaper, cardboard etc. has been reported to have improved fruit quality (Brown and Channel 1-Butcher, 2001), increased growth and subsequent yield (Brown et at., 1995). Among them black polythene and water straw are economical and available in our country. Black plastic is the most popular one because it retards weed growth and warms up the soil during the spring. The black polythene mulch made the harvest earlier in addition to reducing soil water loss. Another important management practice is fertilizer. Fertilizers influenced of plant growth, yield and quality of horticultural crops, particularly color, shape, size, taste, shelf life and processing characteristics. Deficiency of soil nutrient is now considered as one of the major constraints to successful upland crop production in Bangladesh (Islam and Noor, 1982). Phosphorus is one of the important essential macro elements for the normal growth and development of plant. Phosphorous is involved in photosynthesis, respiration, energy storage and transfer, cell division, and enlargement of plant, promotes early root formation and growth, improves quality of fruits, vegetables, and grains. (Khalid, 2006). It also enhances uniform and early crop maturity, improves crop quality and increases resistance to diseases. So, the present investigation was undertaken to determine the proper mulch materials and phosphorus for better vegetative growth and yield of squash.

\section{Materials and Methods}

\subsection{Experimental site and frame work}

The soil of the experimental field belongs to the Tejgaon series under the Agro ecological Zone, Madhupur Tract (AEZ- 28) and the general soil type is Shallow Red Brown Terrace soil. The two factorial experiment was laid out in a
Randomized Complete Block Design (RCBD) with three replications. The total area of the experimental plot was $178.08 \mathrm{~m}^{2}$ with length $21.2 \mathrm{~m}$ and width $8.4 \mathrm{~m}$. The total area was divided into three equal blocks. Each block was divided into 9 plots where 9 treatments combination were distributed randomly. There were 27 unit plots altogether in the experiment. The size of each plot was $1.8 \mathrm{~m} \times 1.8 \mathrm{~m}$. The experiment comprised of two factors: 3 different mulches $\left(\mathrm{M}_{0^{-}}\right.$No mulch, $\mathbf{M}_{1}$ - Rice straw and $\mathbf{M}_{2-}$ Black polythene) and 3 levels of phosphorus $\left(\mathrm{P}_{0}\right.$

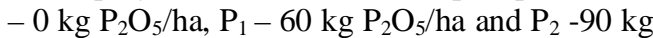
$\left.\mathrm{P}_{2} \mathrm{O}_{5} / \mathrm{ha}\right)$. There were in total $9(3 \times 3)$ treatment combinations such as $\mathrm{M}_{0} \mathrm{P}_{0}, \mathrm{M}_{0} \mathrm{P}_{1}, \mathrm{M}_{0} \mathrm{P}_{2}, \mathrm{M}_{1} \mathrm{P}_{0}$, $\mathrm{M}_{1} \mathrm{P}_{1}, \mathrm{M}_{1} \mathrm{P}_{2}, \mathrm{M}_{2} \mathrm{P}_{0}, \mathrm{M}_{2} \mathrm{P}_{1}, \mathrm{M}_{2} \mathrm{P}_{2}$. Urea, triple super phosphate (TSP), muriate of potash (MP), were used as a source of nitrogen, phosphorous, potassium respectively. Cow dung, urea, muriate of potash (MP), were applied at the rate of 10 tons $/$ ha $365 \mathrm{~kg} / \mathrm{ha}, 223 \mathrm{~kg} / \mathrm{ha}$ respectively following some research work above squash was done in abroad and BARI recommendation for cucurbitaceous crop (Krishi Projuktir Hat Boi). Phosphorous were applied as per treatment.

\subsection{Polybag preparation and raising of seedlings}

Polybag was prepared on 28 October 2015 for raising seedlings of squash and the size of the polybag was 8-inch length and 5-inch breadth. Loose soil was used for polybag preparation. Cow dung was mixed with soil in polybag for better growth of plant. The soil was treated by Sevin 50WP @ 5kg/ha to protect the seed and young plants from the attack of ants. Seeds were sown on 30 October 2015 in the polybag. Light watering and weeding were done several times. No chemical fertilizers were applied for raising of seedlings. Seedlings were not attacked by any kind of insect or disease. Healthy and 15 days old seedlings were transplanted into the experimental field on 21 November 2015.

\subsection{Transplanting of seedlings}

The seedbed was watered before uprooting the seedlings to minimize the damage of roots. Fifteen days old healthy seedlings were 
transplanted at the spacing of $90 \mathrm{~cm} \times 90 \mathrm{~cm}$ in the experimental plots on 21 November 2015. Thus the four plants were accommodated in each unit plot. Planting was done in the afternoon and light irrigation was given immediately after transplanting around each seedling for their better establishment. Watering was done up to five days until they became capable of establishing on their own root system.

\subsection{Data Recording and Analysis}

Data were recorded for yield and its contributing characters such as plant height $(\mathrm{cm})$, number of leaves per plant, total number of male and female flower, number of marketable fruits per plant, fruit length $(\mathrm{cm})$, fruit diameter $(\mathrm{cm})$, fruit weight $(\mathrm{g})$, yield per plant $(\mathrm{kg})$, and yield per ha (t). Collected data were statistically analyzed using MSTAT-C computer package program.

\section{Results and Discussion}

\subsection{Plant height}

Application of mulching exhibited a significant influence on plant height of squash at 45 days after transplanting (DAT). At 45 DAT the tallest plant $\left(56.38 \mathrm{~cm}\right.$ ) was measured from $\mathrm{M}_{2}$ (black polythene) treatment and the shortest $(47.83 \mathrm{~cm})$ was recorded from control treatment $\mathrm{M}_{0}$ (Table 1). Vegetative growth improvement might be explained in view that plastic mulches improve moisture conservation and availability, which ultimately leads to improve plant height. Odedara (2011) reported similar result in case of musk melon. Plant height of squash showed statistically significant variation due to different levels of phosphorus at 45 DAT. At 45 DAT, the tallest plant $(53.63 \mathrm{~cm})$ was measured from $\mathrm{P}_{2}$ (90 kg $\mathrm{P}_{2} \mathrm{O}_{5} / \mathrm{ha}$ ) treatment and the shortest (49.31 $\mathrm{cm})$ was recorded from $\mathrm{P}_{0}$ treatment (Table 1). Combined effect of different mulch materials and levels of phosphorus showed statistically significant variation in terms of plant height of squash at 45 DAT. The tallest plant height (61.23 $\mathrm{cm}$ ) was measured from $\mathrm{M}_{2} \mathrm{P}_{2}$ (black polythene with $90 \mathrm{~kg} \mathrm{P}_{2} \mathrm{O}_{5} /$ ha) treatment combination and the shortest $(47.55 \mathrm{~cm})$ was recorded from $\mathrm{M}_{0} \mathrm{P}_{0}$ (control) which was statistically identical to $\mathrm{M}_{0} \mathrm{P}_{1}, \mathrm{M}_{0} \mathrm{P}_{2}, \mathrm{M}_{1} \mathrm{P}_{0}$ treatment combinations at 45 DAT (Table 2). From the results, it is noticeable that mulching and phosphorus are helpful for increasing plant height of squash.

Table 1. Effect of mulch materials and phosphorus on plant height $(\mathrm{cm})$ and number of leaves per plant at days after transplanting of squash

\begin{tabular}{ccccccccc}
\hline \multirow{2}{*}{$\begin{array}{c}\text { Treat } \\
\text { ment }\end{array}$} & \multicolumn{7}{c}{ Plant height $(\mathrm{cm})$ at } \\
\cline { 2 - 9 } & 15 DAT & 25 DAT & 35 DAT & 45 DAT & 15 DAT & 25 DAT & 35 DAT & 45 DAT \\
\hline $\mathrm{M}_{0}$ & 18.80 & $35.43 \mathrm{c}$ & $46.50 \mathrm{c}$ & $47.83 \mathrm{c}$ & 7.66 & $17.88 \mathrm{c}$ & $22.44 \mathrm{c}$ & $24.11 \mathrm{c}$ \\
$\mathrm{M}_{1}$ & 23.36 & $36.79 \mathrm{~b}$ & $48.60 \mathrm{~b}$ & $50.06 \mathrm{~b}$ & 8.40 & $21.37 \mathrm{~b}$ & $25.07 \mathrm{~b}$ & $26.77 \mathrm{~b}$ \\
$\mathrm{M}_{2}$ & 25.03 & $40.48 \mathrm{a}$ & $54.91 \mathrm{a}$ & $56.38 \mathrm{a}$ & 9.70 & $24.07 \mathrm{a}$ & $29.89 \mathrm{a}$ & $31.77 \mathrm{a}$ \\
\hline Labels of phosphorus & & & & & & \\
\hline $\mathrm{P}_{0}$ & 20.58 & $35.82 \mathrm{c}$ & $48.03 \mathrm{c}$ & $49.31 \mathrm{c}$ & 7.88 & $18.99 \mathrm{c}$ & $22.85 \mathrm{c}$ & $24.48 \mathrm{c}$ \\
$\mathrm{P}_{1}$ & 22.48 & $37.65 \mathrm{~b}$ & $49.69 \mathrm{~b}$ & $51.33 \mathrm{~b}$ & 8.29 & $21.03 \mathrm{~b}$ & $26.33 \mathrm{~b}$ & $28.03 \mathrm{~b}$ \\
$\mathrm{P}_{2}$ & 24.14 & $39.22 \mathrm{a}$ & $52.29 \mathrm{a}$ & $53.63 \mathrm{a}$ & 9.59 & $23.29 \mathrm{a}$ & $28.22 \mathrm{a}$ & $30.14 \mathrm{a}$ \\
\hline
\end{tabular}

In a column means having similar letter (s) are statistically similar and those having different letter (s) differ significantly at $5 \%$ level of probability 
Table 2. Combined Effect of mulches and phosphorus on plant height $(\mathrm{cm})$ and number of leaves per plant at days after transplanting of squash

\begin{tabular}{lcccccccc}
\hline \multirow{2}{*}{$\begin{array}{l}\text { Treatm } \\
\text { ents }\end{array}$} & \multicolumn{3}{c}{ Plant height $(\mathrm{cm})$ at } & \multicolumn{4}{c}{ Number of leaves per plant at } \\
\cline { 2 - 8 } & 15 DAT & 25 DAT & 35 DAT & 45 DAT & 15 DAT & 25 DAT & 35 DAT & 45 DAT \\
\hline $\mathrm{M}_{0} \mathrm{P}_{0}$ & $17.46 \mathrm{e}$ & $34.67 \mathrm{f}$ & $46.14 \mathrm{~g}$ & $47.55 \mathrm{e}$ & 7.44 & $15.99 \mathrm{f}$ & $20.00 \mathrm{f}$ & $21.66 \mathrm{f}$ \\
$\mathrm{M}_{0} \mathrm{P}_{1}$ & $18.28 \mathrm{e}$ & $35.27 \mathrm{ef}$ & $46.05 \mathrm{~g}$ & $47.65 \mathrm{e}$ & 7.66 & $17.00 \mathrm{f}$ & $22.55 \mathrm{e}$ & $24.22 \mathrm{e}$ \\
$\mathrm{M}_{0} \mathrm{P}_{2}$ & $20.67 \mathrm{~d}$ & $36.34 \mathrm{e}$ & $47.32 \mathrm{f}$ & $48.28 \mathrm{e}$ & 7.89 & $20.66 \mathrm{de}$ & $24.78 \mathrm{~cd}$ & $26.44 \mathrm{~d}$ \\
$\mathrm{M}_{1} \mathrm{P}_{0}$ & $21.51 \mathrm{~d}$ & $35.45 \mathrm{ef}$ & $46.52 \mathrm{fg}$ & $48.06 \mathrm{e}$ & 7.78 & $19.22 \mathrm{e}$ & $23.55 \mathrm{de}$ & $25.11 \mathrm{e}$ \\
$\mathrm{M}_{1} \mathrm{P}_{1}$ & $23.43 \mathrm{c}$ & $36.70 \mathrm{~d}$ & $48.97 \mathrm{e}$ & $50.76 \mathrm{~d}$ & 8.66 & $21.33 \mathrm{~d}$ & $25.55 \mathrm{c}$ & $27.22 \mathrm{~cd}$ \\
$\mathrm{M}_{1} \mathrm{P}_{2}$ & $25.16 \mathrm{~b}$ & $38.22 \mathrm{c}$ & $50.31 \mathrm{~d}$ & $51.37 \mathrm{~cd}$ & 8.77 & $23.55 \mathrm{bc}$ & $26.11 \mathrm{c}$ & $28.00 \mathrm{c}$ \\
$\mathrm{M}_{2} \mathrm{P}_{0}$ & $22.79 \mathrm{c}$ & $37.34 \mathrm{~d}$ & $51.42 \mathrm{c}$ & $52.33 \mathrm{c}$ & 8.44 & $21.78 \mathrm{~cd}$ & $25.00 \mathrm{~cd}$ & $26.66 \mathrm{~d}$ \\
$\mathrm{M}_{2} \mathrm{P}_{1}$ & $25.72 \mathrm{~b}$ & $40.99 \mathrm{~b}$ & $54.04 \mathrm{~b}$ & $55.59 \mathrm{~b}$ & 8.55 & $24.78 \mathrm{ab}$ & $30.89 \mathrm{~b}$ & $32.66 \mathrm{~b}$ \\
$\mathrm{M}_{2} \mathrm{P}_{2}$ & $26.59 \mathrm{a}$ & $43.12 \mathrm{a}$ & $59.24 \mathrm{a}$ & $61.23 \mathrm{a}$ & 12.11 & $25.66 \mathrm{a}$ & $33.77 \mathrm{a}$ & $36.00 \mathrm{a}$ \\
\hline
\end{tabular}

In a column means having similar letter (s) are statistically similar and those having different letter (s) differ significantly at $5 \%$ level of probability

Table 3. Effect of mulches and phosphorus on yield and yield attributing parameter of squash

\begin{tabular}{cccccccc}
\hline Treatment & $\begin{array}{l}\text { Number } \\
\text { of male } \\
\text { flowers } \\
\text { per plant }\end{array}$ & $\begin{array}{l}\text { Number } \\
\text { of female } \\
\text { flowers } \\
\text { per plant }\end{array}$ & $\begin{array}{l}\text { Number of } \\
\text { marketable } \\
\text { fruits per } \\
\text { plant }\end{array}$ & $\begin{array}{l}\text { Length } \\
\text { of fruit } \\
(\mathrm{cm})\end{array}$ & $\begin{array}{l}\text { Diameter } \\
\text { of fruit } \\
(\mathrm{cm})\end{array}$ & $\begin{array}{l}\text { Weight of } \\
\text { individual } \\
\text { fruit }(\mathrm{g})\end{array}$ & $\begin{array}{l}\text { Fruit yield } \\
\text { per plant } \\
(\mathrm{kg})\end{array}$ \\
\hline \multicolumn{2}{l}{ Mulch Materials } \\
\hline $\mathrm{M}_{0}$ & $16.85 \mathrm{c}$ & $13.92 \mathrm{c}$ & $6.14 \mathrm{c}$ & $17.67 \mathrm{c}$ & $4.54 \mathrm{c}$ & $280.83 \mathrm{~b}$ & $1.76 \mathrm{c}$ \\
$\mathrm{M}_{1}$ & $19.00 \mathrm{~b}$ & $15.77 \mathrm{~b}$ & $8.07 \mathrm{~b}$ & $19.42 \mathrm{~b}$ & $5.57 \mathrm{~b}$ & $281.84 \mathrm{~b}$ & $2.34 \mathrm{~b}$ \\
$\mathrm{M}_{2}$ & $20.92 \mathrm{a}$ & $18.29 \mathrm{a}$ & $9.85 \mathrm{a}$ & $21.15 \mathrm{a}$ & $7.11 \mathrm{a}$ & $328.00 \mathrm{a}$ & $3.07 \mathrm{a}$ \\
\hline Labels of phosphorus & & & & & & \\
\hline \multicolumn{2}{c}{$17.66 \mathrm{c}$} & $15.22 \mathrm{~b}$ & $7.18 \mathrm{c}$ & $18.86 \mathrm{c}$ & $5.34 \mathrm{c}$ & $290.42 \mathrm{~b}$ & \\
$\mathrm{P}_{0}$ & $18.74 \mathrm{~b}$ & $16.07 \mathrm{ab}$ & $8.11 \mathrm{~b}$ & $19.36 \mathrm{~b}$ & $5.68 \mathrm{~b}$ & $300.43 \mathrm{a}$ & $2.39 \mathrm{~b}$ \\
$\mathrm{P}_{1}$ & $20.37 \mathrm{a}$ & $16.70 \mathrm{a}$ & $8.78 \mathrm{a}$ & $20.02 \mathrm{a}$ & $6.19 \mathrm{a}$ & $299.82 \mathrm{a}$ & $2.58 \mathrm{a}$ \\
\hline
\end{tabular}

In a column means having similar letter (s) are statistically similar and those having different letter (s) differ significantly at $5 \%$ level of probability

\subsection{Number of leaves per plant}

Number of leaves per plants was significantly influenced by different mulching at 45 . At 45 DAT, maximum numbers of leaves (31.77) plant $^{-}$ 1 were observed from $\mathrm{M}_{2}$ (black polythene) treatment and minimum numbers of leaves (24.11) plant $^{-1}$ were recorded from $\mathrm{M}_{0}$ treatment (Table 1). The extended retention of moisture and availability of moisture also leading to higher uptake of nutrient for proper growth and development of plants, resulted maximum number of leaves, as compared to control. Aniekwe (2015), Roudan and Vahid (2015) found similar result in case of squash. Significant variation was recorded due to different level of phosphorus intense of number of leaves per plant at 45 DAT. Maximum numbers of leaves (30.14) plant $^{-1}$ were found from $\mathrm{P}_{2}\left(90 \mathrm{~kg} \mathrm{P}_{2} \mathrm{O}_{5} / \mathrm{ha}\right)$ treatment and minimum numbers of leaves (24.48) plant $^{-1}$ were found from $\mathrm{P}_{0}$ treatment at 45 DAT (Table 1). This result was conformity with result found by Narke et al. (2015) and 
Naik (2016) in case of squash. Different mulching and different levels of phosphorus showed significant differences due to their combined effect on number of leaves per plant of squash at 45 DAT. At 45 DAT, the maximum numbers of leaves (36.00) plant $^{-1}$ were observe in $\mathrm{M}_{2} \mathrm{P}_{2}$ (black polythene with $90 \mathrm{~kg} \mathrm{P}_{2} \mathrm{O}_{5} / \mathrm{ha}$ ) treatment combination and minimum numbers of leaves (21.66) plant $^{-1}$ were observed in $\mathrm{M}_{0} \mathrm{P}_{0}$ treatment combination (Table 2). It was revealed that the combined effect of black polythene and $90 \mathrm{~kg} \mathrm{P}_{2} \mathrm{O}_{5} /$ ha increased number of leaves plant ${ }^{-1}$ of squash of $\mathrm{M}_{0} \mathrm{P}_{0}$ (control) which was closely followed by $\mathrm{M}_{0} \mathrm{P}_{1}, \mathrm{M}_{1} \mathrm{P}_{1}$ treatment combination.

\subsection{Number of male flowers per plant}

Number of male flowers per plant showed statistically significant variation due to different mulching of squash. The maximum number of male flowers (20.92) plant $^{-1}$ was recorded from $\mathrm{M}_{2}$ (black polythene) treatment, whereas the minimum number of male flowers (16.85) plant $^{-1}$ was found from $\mathrm{M}_{0}$ (control) treatment (Table 3). Mahadeen (2014) also reported similar findings from his experiment. There was significant effect of different levels of phosphorus on the number of male flowers per plant. The highest number of male flowers (20.37) plant $^{-1}$ was found from $\mathrm{P}_{2}$ (90 kg $\mathrm{P}_{2} \mathrm{O}_{5} / \mathrm{ha}$ ) treatment while the lowest number of male flowers (17.66) plant $^{-1}$ was found from $\mathrm{P}_{0}$ (control) treatment (Table 3). Sahar et al. (2005) also observed the similar findings in case of squash. Combined effect of different mulching and levels of phosphorus showed statistically significant variation in terms of number of male flowers per plant of squash. The maximum number of male flowers (22.22) plant ${ }^{-1}$ was observed from $\mathrm{M}_{2} \mathrm{P}_{2}$ (black polythene with $90 \mathrm{~kg} \mathrm{P}_{2} \mathrm{O}_{5} / \mathrm{ha}$ ) treatment combination and the minimum number of male flowers (16.11) plant $^{-1}$ was recorded from $\mathrm{M}_{0} \mathrm{P}_{0}$ (control) treatment combination, which was statistically similar to $\mathrm{M}_{0} \mathrm{P}_{1}$ treatment combination (Table 4).

\subsection{Number of female flower per plant}

A significant variation due to the effect of mulching was found on number of female flowers per plant. The highest number of female flowers (18.29) plant $^{-1}$ was recorded in $\mathrm{M}_{2}$ (black polythene) treatment and the lowest number of female flowers (13.92) plant $^{-1}$ was recorded from $\mathrm{M}_{0}$ (control) treatment (Table 3). The results indicated that maximum female flowers in number were produced by the application of black polythene compared with the control. Mahadeen (2014) reported similar findings from his experiment in case of squash. Effect of different levels of phosphorus was also statistically significant on number of female flowers plant ${ }^{-1}$. The maximum number of female flowers (16.70) plant $^{-1}$ was recorded from $\mathrm{P}_{2}(90$ $\mathrm{kg} \mathrm{P}_{2} \mathrm{O}_{5} / \mathrm{ha}$ ) treatment and the minimum number of female flowers (15.22) plant $^{-1}$ was recorded from $\mathrm{P}_{0}$ (control) treatment (Table 3 ). This might be due to the fact that phosphorus fertilizer promoted femaleness in plants. Umamaheswarappa et al. (2005) reported the similar results from their earlier experiments in case of squash. Number of female flowers per plant varied significantly due to the combined effect of different mulching and different levels of phosphorus. The highest number of female flowers (19.11) plant $^{-1}$ was recorded from the treatment combination $\mathrm{M}_{2} \mathrm{P}_{2}$ (black polythene with $90 \mathrm{~kg} \mathrm{P}_{2} \mathrm{O}_{5} / \mathrm{ha}$ ) which was closely followed by $\mathrm{M}_{2} \mathrm{P}_{1}$ (18.55) and the lowest number of female flowers (13.22) plant $^{-1}$ was recorded from the treatment combination $\mathrm{M}_{0} \mathrm{P}_{0}$ (Table 4).

\subsection{Number of marketable fruits per plant}

Different mulch materials showed a statistically significant variation on number of marketable fruits per plant. Marketable fruits per plant showed a gradual increasing trend for different mulching comparing the control. The maximum (9.85) marketable fruits plant $^{-1}$ in number were recorded from $\mathrm{M}_{2}$ (black polythene) treatment and the minimum (6.14) marketable fruits plant ${ }^{-1}$ were recorded in $\mathrm{M}_{0}$ (Table 3). Mutetwa and Mtaita (2014) stated that marketable fruit yield significantly improved by the use of a silverygrey colored plastic mulch compared to the blue colored and wheat straw mulch. Number of marketable fruits per plant varied significantly due to different levels of phosphorus. The maximum (8.78) number of marketable fruits 
plant $^{-1}$ was recorded in application of $\mathrm{P}_{2}(90 \mathrm{~kg}$ $\mathrm{P}_{2} \mathrm{O}_{5} / \mathrm{ha}$ ) treatment and the minimum (7.18) number of marketable fruit plant $^{-1}$ in number were recorded in $\mathrm{P}_{0}$ (control condition). The results indicated that maximum fruits per plant were produced by the application of phosphorus than the control with ensuring the better yield of squash. Mulching and phosphorus showed a statistically significant variation in consideration of fruits per plant in number. The maximum (10.22) number of marketable fruit plant ${ }^{-1}$ was recorded in the treatment combination $\mathrm{M}_{2} \mathrm{P}_{2}$ (black polythene with $90 \mathrm{~kg} \mathrm{P}_{2} \mathrm{O}_{5} / \mathrm{ha}$ ) and the minimum (5.11) was recorded in the treatment combination $\mathrm{M}_{0} \mathrm{P}_{0}$ (control condition) (Table 4). The results indicated that combination of mulching and phosphorus ensures the optimum condition for the growth and development of squash and the ultimate result is the maximum marketable fruits plant ${ }^{-1}$.

\subsection{Length of fruit (cm)}

Statistically significant variation was recorded in terms of length of fruit due to different mulching. The maximum $(21.15 \mathrm{~cm})$ fruit length was recorded from $\mathrm{M}_{2}$ (black polythene) treatment (Table 3) and the minimum $(17.67 \mathrm{~cm})$ length of fruit was recorded in $\mathrm{M}_{0}$ (control) (Table 3). The researchers indicated that plants under polyethylene mulch produce larger fruit and have higher fruit yield per plant because of the better plant growth that due to favorable hydro-thermal regime of soil and complete weed free environment. Bhutia (2011) found that fruit length was recorded highest in black plastic mulch than green plastic mulch. Phosphorus had significant effect on length of fruit. The maximum $(20.02 \mathrm{~cm})$ length of fruit was recorded from $\mathrm{P}_{2}\left(90 \mathrm{~kg} \mathrm{P}_{2} \mathrm{O}_{5} / \mathrm{ha}\right)$ treatment and the minimum $(18.86 \mathrm{~cm})$ length of fruit was recorded in case of $\mathrm{P}_{0}$ (control) treatment (Table 3). Naik and Srinivas (1992) found similar result in case of squash. Combined effect of mulching and phosphorus showed a statistically significant variation in length of fruit. The maximum (21.79 $\mathrm{cm})$ fruit length was recorded in the treatment combination of $\mathrm{M}_{2} \mathrm{P}_{2}$ (black polythene with 90 $\mathrm{kg} \mathrm{P}_{2} \mathrm{O}_{5} / \mathrm{ha}$ ) which was closely followed by $\mathrm{M}_{2} \mathrm{P}_{1}$ and the minimum $(17.12 \mathrm{~cm})$ was recorded in the treatment combination of $\mathrm{M}_{0} \mathrm{P}_{0}$ (control), which was closely followed by $\mathrm{M}_{0} \mathrm{P}_{1}$ shown in Table 4 .

Table 4. Combined effect of mulches and phosphorus on yield and yield attributing parameter of squash

\begin{tabular}{|c|c|c|c|c|c|c|c|c|}
\hline $\begin{array}{c}\text { Treatm } \\
\text { ents }\end{array}$ & $\begin{array}{c}\text { Number } \\
\text { of male } \\
\text { flowers } \\
\text { per } \\
\text { plant }\end{array}$ & $\begin{array}{l}\text { Number } \\
\text { of female } \\
\text { flowers } \\
\text { per plant }\end{array}$ & $\begin{array}{c}\text { Number of } \\
\text { marketable } \\
\text { fruits per } \\
\text { plant }\end{array}$ & $\begin{array}{l}\text { Length } \\
\text { of fruit } \\
\text { (cm) }\end{array}$ & $\begin{array}{l}\text { Diameter } \\
\text { of fruit } \\
(\mathrm{cm})\end{array}$ & $\begin{array}{l}\text { Weight of } \\
\text { individual } \\
\text { fruit }(\mathrm{g})\end{array}$ & $\begin{array}{l}\text { Fruit } \\
\text { yield } \\
\text { per } \\
\text { plant } \\
(\mathrm{kg})\end{array}$ & $\begin{array}{c}\text { Fruit } \\
\text { yield per } \\
\text { hectare } \\
\text { (t) }\end{array}$ \\
\hline $\mathrm{M}_{0} \mathrm{P}_{0}$ & $16.11 \mathrm{~g}$ & $13.22 \mathrm{~g}$ & $5.11 \mathrm{e}$ & $17.12 \mathrm{~h}$ & $4.23 \mathrm{f}$ & $272.24 d$ & $1.60 \mathrm{~h}$ & $19.73 \mathrm{~h}$ \\
\hline $\mathrm{M}_{0} \mathrm{P}_{1}$ & $16.67 \mathrm{fg}$ & $13.89 \mathrm{fg}$ & $6.44 \mathrm{~d}$ & $17.73 \mathrm{gh}$ & $4.44 \mathrm{f}$ & $280.75 \mathrm{~cd}$ & $1.77 \mathrm{gh}$ & $21.83 \mathrm{~g}$ \\
\hline $\mathrm{M}_{0} \mathrm{P}_{2}$ & $17.78 \mathrm{de}$ & 14.67efg & $6.89 \mathrm{~d}$ & $18.16 \mathrm{fg}$ & $4.94 \mathrm{e}$ & $289.50 \mathrm{bcd}$ & $1.90 \mathrm{~g}$ & $23.18 \mathrm{~g}$ \\
\hline $\mathrm{M}_{1} \mathrm{P}_{0}$ & $17.22 \mathrm{ef}$ & $15.22 \mathrm{def}$ & $6.89 \mathrm{~d}$ & $18.89 \mathrm{ef}$ & $5.07 \mathrm{de}$ & $280.88 \mathrm{~cd}$ & $2.15 \mathrm{f}$ & $25.14 \mathrm{f}$ \\
\hline $\mathrm{M}_{1} \mathrm{P}_{1}$ & $18.66 \mathrm{~d}$ & $15.77 \mathrm{cde}$ & $8.11 \mathrm{c}$ & $19.27 \mathrm{de}$ & $5.53 \mathrm{~d}$ & $292.99 \mathrm{bcd}$ & $2.32 \mathrm{e}$ & $28.08 \mathrm{e}$ \\
\hline $\mathrm{M}_{1} \mathrm{P}_{2}$ & $21.11 \mathrm{~b}$ & $16.33 \mathrm{~cd}$ & $9.23 b$ & $20.11 \mathrm{~cd}$ & $6.11 \mathrm{c}$ & $271.70 d$ & $2.54 \mathrm{~d}$ & $30.80 \mathrm{~d}$ \\
\hline $\mathrm{M}_{2} \mathrm{P}_{0}$ & $19.67 \mathrm{c}$ & $17.22 b c$ & $9.55 b$ & $20.58 b c$ & $6.72 b$ & $318.11 b c$ & $2.84 \mathrm{c}$ & $34.01 \mathrm{c}$ \\
\hline $\mathrm{M}_{2} \mathrm{P}_{1}$ & $20.89 b$ & $18.55 \mathrm{ab}$ & $9.78 \mathrm{ab}$ & $21.09 \mathrm{ab}$ & 7.08ab & $327.55 \mathrm{ab}$ & $3.08 \mathrm{~b}$ & $37.31 \mathrm{~b}$ \\
\hline $\mathrm{M}_{2} \mathrm{P}_{2}$ & $22.22 \mathrm{a}$ & $19.11 \mathrm{a}$ & $10.22 \mathrm{a}$ & $21.79 \mathrm{a}$ & $7.53 \mathrm{a}$ & $338.26 \mathrm{a}$ & $3.29 \mathrm{a}$ & $39.95 \mathrm{a}$ \\
\hline
\end{tabular}

In a column means having similar letter (s) are statistically similar and those having different letter (s) differ significantly at $5 \%$ level of probability. 


\subsection{Diameter of fruit ( $\mathrm{cm}$ )}

Diameter of fruit showed a significant variation in relation with different mulch materials. The lowest $(4.54 \mathrm{~cm})$ average diameter of fruit was recorded in $\mathrm{M}_{0}$ (control) treatment and the highest $(7.11 \mathrm{~cm})$ average diameter of fruit was recorded in $\mathrm{M}_{2}$ (black polythene) treatment (Table 3). Deoraoji and Chandrashekhar (2003) found that fruit characters like diameter of fruit, weight of fruit and fruits per vine showed significant results under grass mulch and black polyethylene mulch in case of squash. The variation in diameter of fruit among the different levels of phosphorus were found to be statistically significant. the maximum $(6.19 \mathrm{~cm})$ diameter of fruit was recorded from $\mathrm{P}_{2}(90 \mathrm{~kg}$ $\mathrm{P}_{2} \mathrm{O}_{5} /$ ha) treatment and the minimum $(5.34 \mathrm{~cm})$ was recorded in $\mathrm{P}_{0}$ (control) treatment (Table 3). It was observed that the combined effect of different mulching and levels of phosphorus on diameter of fruit was statistically significant. The highest $(7.53 \mathrm{~cm})$ average diameter of individual fruit was recorded from the treatment combination $\mathrm{M}_{2} \mathrm{P}_{2}$ (black polythene with $90 \mathrm{~kg}$ $\mathrm{P}_{2} \mathrm{O}_{5} /$ ha) which was statistically similar to $\mathrm{M}_{2} \mathrm{P}_{1}$ treatment combination and the lowest $(10.97 \mathrm{~cm})$ was recorded from the treatment combination of $\mathrm{M}_{0} \mathrm{P}_{0}$ (control) which was statistically identical to $\mathrm{M}_{0} \mathrm{P}_{1}$ treatment combination (Table 4)

\subsection{Individual fruit weight (g)}

Mulching showed a significant influence on fruit weight of squash. The maximum fruit weight (328 g) was measured from $\mathrm{M}_{2}$ (black polythene) treatment and minimum fruit weight $(380.83 \mathrm{~g})$ was recorded from $\mathrm{M}_{0}$ (control) treatment which was statistically identical to $\mathrm{M}_{1}$ treatment (Table 3 ). It was revealed that the fruit weight increased with mulching application. Mulching retain soil moisture that helps to increase fruit weight of squash. Mahadeen (2014) also found that mulches gave higher fruit weight in squash then non-mulched plots. Conformity result was found by Khan et al. (2015) in case of sponge gourd. The analysis of variance given in table 3 revealed that the effect of different levels of phosphorus on weight of individual fruits was statistically influenced. The highest individual fruit weight (300.43 g) was found from $\mathrm{P}_{1}(90 \mathrm{~kg}$ $\mathrm{P}_{2} \mathrm{O}_{5} /$ ha) treatment which was statistically identical to $\mathrm{P}_{2}$ treatment, while the lowest individual fruit weight $(290.42 \mathrm{~g})$ was found from $\mathrm{P}_{0}$ (control) treatment (Table 3). Similar result was found in case of squash by Sahar et al. (2005). There was significant combined effect of different mulching and levels of phosphorus on the weight of individual fruit. The maximum $(338.26 \mathrm{~g})$ fruit weight was recorded in the treatment combination of $\mathrm{M}_{2} \mathrm{P}_{2}$ (black polythene with $90 \mathrm{~kg} \mathrm{P}_{2} \mathrm{O}_{5} / \mathrm{ha}$ ), which was statistically similar to $\mathrm{M}_{2} \mathrm{P}_{1}$ and the minimum (272.24 g) was recorded in the treatment combination of $\mathrm{M}_{0} \mathrm{P}_{0}$ (control) shown in Table 4. The results indicated that combination of mulching and phosphorus ensures the optimum condition for the growth and development of squash and the ultimate result is the maximum fruit weight.

\subsection{Fruit yield per plant (kg)}

Fruit yield per plant was significantly influenced by mulching. The highest fruit yield $(3.07 \mathrm{~kg})$ plant $^{-1}$ was recorded from $\mathrm{M}_{2}$ (black polythene) treatment whereas the lowest fruit yield $(1.76 \mathrm{~kg})$ plant $^{-1}$ was found from $\mathrm{M}_{0}$ (control) treatment (Table 3). Higher yield might be due to sufficient soil moisture near the root zone that ensures better plant growth as expressed in vigorous plant growth. Parmer et al. (2013) found similar result in case of musk melon and Bhutia (2011) in case of bottle gourd. Levels of phosphorus varied significantly in terms of fruit yield per plant of squash. The highest fruit yield $(2.58 \mathrm{~kg})$ plant $^{-1}$ was found from $\mathrm{P}_{2}\left(90 \mathrm{~kg} \mathrm{P}_{2} \mathrm{O}_{5} / \mathrm{ha}\right)$ treatment, while the lowest fruit yield $(2.20 \mathrm{~kg})$ plant $^{-1}$ was found from $\mathrm{P}_{0}$ (control) treatment (Table 3). Phosphorus application increased the fruits yield parameters of the crop which may be attributed to the ability of the phosphorus fertilizer to promote vigorous growth, increased meristematic and physiological activities in the plant due to nutrients supply and improvement in the soil properties, thereby resulting in the synthesis of more photo-assimilates which is used in producing fruits. Sahar et al. (2005) also found the similar response of squash to phosphorus fertilizer in their field experiment. 
Combined effect of different mulching and levels of phosphorus showed statistically significant variation in terms of fruit yield per plant of squash. The highest fruit yield $(3.29 \mathrm{~kg})$ plant $^{-1}$ was observed from $\mathrm{M}_{2} \mathrm{P}_{2}$ (black polythene with
$90 \mathrm{~kg} \mathrm{P}_{2} \mathrm{O}_{5} / \mathrm{ha}$ ) treatment combination and the lowest fruit yield $(1.60 \mathrm{~kg})$ plant $^{-1}$ was recorded from $\mathrm{M}_{0} \mathrm{P}_{0}$ (control) treatment combination which was statistically similar to $\mathrm{M}_{0} \mathrm{P}_{1}$ treatment combination (Table 4).

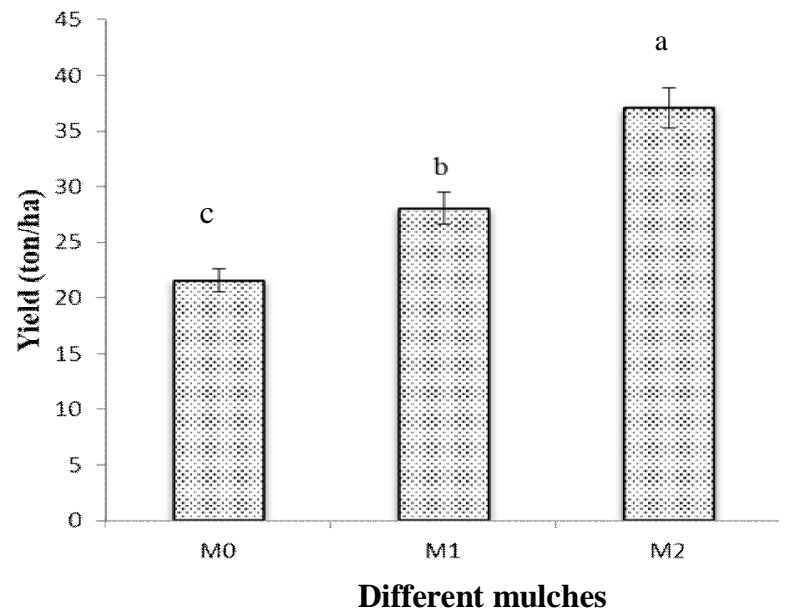

Figure 1. Effect of mulches on fruit yield per hectare (t) of squash $\left(\mathrm{M}_{0}\right.$ : Control, $\mathrm{M}_{1}$ : Rice straw, $\mathrm{M}_{2}$ : Black polythene)

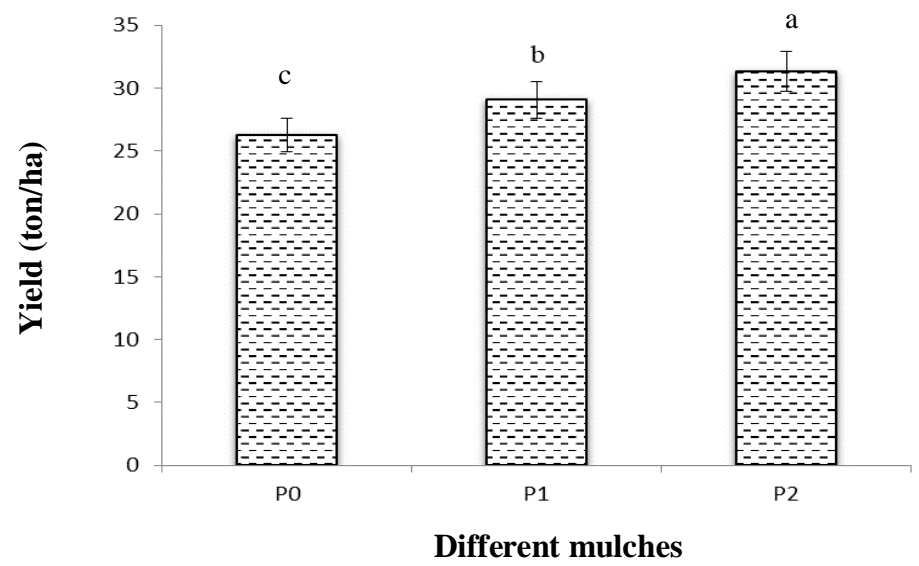

Figure 2. Effect of Phosphorus on yield per hectare (t) of squash $\left(\mathrm{P}_{0}: 0 \mathrm{~kg} \mathrm{P}_{2} \mathrm{O}_{5} / \mathrm{ha}, \mathrm{P}_{1}: 60 \mathrm{~kg} \mathrm{P}_{2} \mathrm{O}_{5} / \mathrm{ha}\right.$, $\left.\mathrm{P}_{2}: 90 \mathrm{~kg} \mathrm{P}_{2} \mathrm{O}_{5} / \mathrm{ha}\right)$ 


\subsection{Fruit yield per hectare $(t)$}

A statistically significant variation was recorded in terms of yield per hectare for different mulching. The maximum $(37.09 \mathrm{t})$ yield ha ${ }^{-1}$ was recorded from $\mathrm{M}_{2}$ (black polythene) treatment (Fig. 1) and the minimum (21.58 t) yield ha ${ }^{-1}$ was recorded in $\mathrm{M}_{0}$ control condition. Qadir (1992) found that polythene mulches resulted higher fruit yield as compared to straw mulched and non-mulched plants. The use of plastic mulch promotes changes in the microclimate of the plant, favoring growth and vigor, production and yield of plants. Khan et al. (2015) found similar result in case of sponge gourd, Odedara (2011) in case of musk melon. Different levels of phosphorus varied significantly in terms of fruit yield per hectare of squash. The highest yield was observed from $\mathrm{P}_{2}(31.32 \mathrm{t}) \mathrm{ha}^{-1}$ treatment and lowest yield was observed from $\mathrm{P}_{1}(26.29 \mathrm{t})$ $\mathrm{ha}^{-1}$ treatment (Fig. 2). Sahar et al. (2005) reported the similar results from their earlier experiment.

The analysis of variance given in table 4, revealed that the combined effect of different mulching and levels of phosphorus on fruit yield per hectare was found to be statistically significant. The maximum $(39.95 \mathrm{t})$ yield $\mathrm{ha}^{-1}$ was recorded in the treatment combination of $\mathrm{M}_{2} \mathrm{P}_{2}$ (black polythene with $90 \mathrm{~kg} \mathrm{P}_{2} \mathrm{O}_{5} / \mathrm{ha}$ ) and the minimum $(19.73 \mathrm{t})$ was recorded in the treatment combination of $\mathrm{M}_{0} \mathrm{P}_{0}$ control condition (Table 4). The results indicated that combination of mulching and phosphorus ensures the optimum condition for the growth and development of squash and the ultimate results is the maximum yield per hectare. Furthermore, increased fruit yield per plant might have contributed towards increased overall fruit yield.

\section{Conclusions}

It may be concluded that use of black polythene mulch and phosphorus at $90 \mathrm{~kg} \mathrm{P}_{2} \mathrm{O}_{5} /$ ha would be suitable for optimum vegetative growth and yield of squash compare to other treatments.

\section{Acknowledgement}

We would like to thank the Department of Horticulture, Sher-e-Bangla Agricultural University, Sher-e-Bangla Nagar, Dhaka, Bangladesh for the support and help to carry out this research work.

\section{References}

Aniekwe, N.L., and Anike, N.T. 2015. Effects of different mulching materials and plant densities on the environment, growth and yield of cucumber. IOSR Journal of Agricultural and Veterinary Sciences, 8(11): 64-72.

Brown, J.E. and Channell-Butcher, C. 1999. Effects of row cover and black plastic mulch on yield of 'AU Producer' watermelon on hilled and flat rows. Journal of vegetable crop production, 5: 67-71

Choudhari, S.M. and More, T.A. 2002. Fertigation, fertilizer and spacing requirnment of tropical gynoecious cucumber hybrids. Acta-Horticulture, 588: 233-240.

Deoraoji and Chandrashekhar, K. 2003. Effect of different mulches and growing conditions in musk melon. MS thesis. Mahatma Phule krishi Vidyapeeth, Rahuri.

Islam, M.S. and Noor, S. 1982. Performance of groundnut under levels of phosphate fertilization in flood plain soil of Jamalpur. Bangladesh Journal of Agriculture Research, 7(1): 35-40.

Khalid, S. M. 2006. Squash (Cucurbita pepo L.) Growth and Yield in Response to Different Types of Fertilizers. MS thesis. University of Khartoum, Sudan.

Khan, S., Pal, M. and Kumar, V. 2015. Influence of different mulches on growth and yield of sponge gourd (Luffa cylindrica L.). Plant Archives, 15(1): 393-395. 
Mahadeen, A.Y. 2014. Effect of polyethylene black plastic mulch on growth and yield of two summer vegetable crops under rain-feed conditions under semi-arid region conditions. American Journal of Agricultural Biological Sciences, 9(2): 202-207

Mohammad, B.E et al. 2011. Climatic suitability of growing summer squash (cucurbita pepo L.) as a medicinal plant in Iran. Notulae Scientia Biologicae, 3(2):39-46.

Mutetwa, M and Mtaita, T. 2014. Effect of different mulch colors on cucumber production. Journal of Global Innovative and Agricultural Society Science, 2(4): 178-184.

Naik H.P. 2016. Effect of different levels of fertilizer on growth and yield of $F_{1}$ hybrids of cucumbers under konkana groclimatic conditions. M.Sc.(Agri.) thesis, Dr. B. S. K. K. V., Dapoli, India.

Naik, L.B. and Srinivas, K. 1992. Influence of nitrogen and phosphorus fertilization on seed crop of cucumber (Cucumis sativus). Indian Journal of Agronomy, 37(4):769771.

Odedara, M.D. 2011. Effect of different mulches on growth, yield and quality of musk melon cv. Sweet Queen, JAU, Junagadh.

Qadir, M.A. 1992. Mulching effects on fruit yield of watermelon. Agricultural Science Digest, 12(1): 1-3.
Roudan, M.A and Vahid, A. 2015. Mulch effect on the characteristics of the Lays cucumber (Cucumis sativus) greenhouse in city Rudan. Journal of Novel Applied Sciences, 4(8): 864-867.

Sahar, T et al. 2005. Effect of seedling age and different levels of phosphorus on growth and yield of cucumber (Cucumis sativus L). International Journal of Agricultural Biology, 7(2): 311-314.

Tamer, C.E et al. 2010. Evaluation of several quality criteria of low calorie pumpkin dessert. Notulae Botanicae Horti Agrobotanici Cluj, 38:76 - 80.

Umamaheswarappa, V et al. 2005. Effect of Varied Levels of Nitrogen, Phosphorus and Potassium on Flowering, Fruit Set and Sex Ratio of Cucumber. Karnataka Journal of Agricultural Sciences, 18 (3):744-747.

Albert, S. 2018. Zucchini Growing Quick Tips. Harvest to Table. DOI: https://harvesttotable.com/zucchinigrowing-quick-tips/. Date: 27 April, 2018

Bhutia, T. L. 2011. Studies on the effect of mulches and nitrogen on growth, yield and quality of bottle gourd (Lagenaria siceraria) Moench. Doi: http:// krishikosh. egranth.ac.in/handle/1/69331. Date: 31 October, 2018 